\title{
保修技術継承のための学習支援システム
}

\section{CAI System for Inheritance of Maintenance Expertise}

\author{
$\underset{\substack{\text { 尾暮 拓也 } \\ \text { Takuya Ogure }}}{ }$ \\ 東京大学大学院 工学系研究科 システム量子工学専攻 \\ QUEST, The Univ. of Tokyo. \\ ogure@sk.q.t.u-tokyo.ac.jp \\ 花房 英光 \\ 株式会社原子力安全システム研究所 \\ Institute of Nuclear Safety System. \\ hanafusa@inss.co.jp

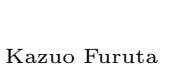 \\ 東京大学大学院 新領域創成科学研究科 環境学専攻 \\ Graduate School of Frontier Sciences, The Univ. of Tokyo \\ furuta@k.u-tokyo.ac.jp
}

keywords: CAI, inheritance, maintenance expertise, ontology.

\section{Summary}

Generally, maintenance tasks need various knowledge, which includes empirical knowledge of experienced experts. This led our interest to inheritance of maintenance expertise.

We thought any powerful methodology for the purpose must be discussed, and it will never be achieved without dealing with background knowledge of maintenance. From this viewpoint, we analyzed educational documents about maintenance in order to derive representation of such background knowledge. This discussion lead to "maintenance ontology", and a particular representation constructed with three knowledges; knowledge about design process, knowledge about trouble occurrence, and free style document. The free style document is prepared as additional description of the other two knowledges, and besides description of empirical knowledge. The empirical knowledge would be described in context of design and trouble occurrence.

We have developed a prototype CAI system and asked maintenance experts to evaluate it. The result of the evaluation was totally satisfactory, and so we concluded the proposed methodology significant.

\section{1.はじめに}

プラントや航空機などの大規模機械の保修には一般に 対象に関する膨大な知識が要求されるので, 保修技術者 には相応の教育が必要となる . またベテランの保修技術 者の引退に伴い , 知識が散逸するのを防ぐことも重要な 課題である.

ここで技術者の教育，訓練方法に関して比較的整備さ れている原子力分野を例にとると，保修技術者は入社時 の導入教育で運転など実習を受けた後，保修業務に従事 しながら，レベルに合わせ，専門の訓練施設である保修 訓練センターでテキストを用いた講義と実機を模擬した 訓練用モデルを用いた実習が行われている．また技術力 を確保するため，プラントの定期検査時に直営作業で行 うことによって技術を習得している。

一方, 知的 CAI システム一般の研究に関しては溝口が まとめている [溝口 95] が, 特に原子力分野における教育 支援に関しては小型シミュレータ, フルスコープシミュ レータや CAI 指向シミュレータなどの運転訓練シミュ レータが古くから用いられ，これらの効果を久保田らが まとめている [久保田 96] .このほかコンピュータゲーム
の要素を取り込んだ CAI の研究 [久保田 93]や, 緊急時 運転手順の教育に関する研究 [横山 93] などの研究がある.

一方保修技術者のための訓練支援システムに関しては， 仮想現実空間上に保修対象機器を構築し，これを操作し て保修手順を実習することができる VR システムが研究 されている[Ishii 96] .

保修技術者の保修に関する知識を，講義など教育によっ て得られる「教科知識」と機器の操作などの訓練を通じ て得られる「保修タスク実施知識」とに区別して対比し た時，前者が後者の背景知識となっていることは明白で あるにもかかわらず, この部分の教育支援研究は手薄で あるように見える.乥こで本研究では，この教科知識に 焦点をあてた教育支援システムについて検討する .

また一方で，ベテランの技術を構成する知識は，この ような教科知識を基礎として，これと有機的に関連して いるはずである . 教育支援システムにベテランの経験的 知識を動的に挿入する方法を付加することができれば， 兴の教育支援システムは知識共有も支援できると期待さ れる. 光こで本研究ではこのような技術継承問題も視野 に入れた上で，

(1) 保修オントロジーの検討. 
（2）オントロジーに立脚した知識表現の提案と，これ の試作システムへの実装 .

(3) 知識表現の評価.

の 3 つを目的とする .

\section{2. 保修オントロジーの検討}

\section{$2 \cdot 1$ オントロジー}

「オントロジー」という語にはさまざまな定義がある [溝口 97] が, 本研究では「知識表現を決定するための暗 黙の仮定を明示化するための議論」と定義し，本論文で は特に「保修タスク実施知識」光のものではなく，光の 背景知識となっている「教科知識」に焦点を絞った保修 オントロジーの検討を行って，知識表現の提案をする．

\section{$2 \cdot 2$ 教科知識の分析}

関西電力原子力保修訓練センターで教育に利用される 印刷物には，実習時に用いられる作業手順マニュアルと 座学の講義に用いられるテキスト教材があり，ここでテ キスト教材は教科知識のよい例である .このテキスト教 材を分析した結果，内容を次の 3 つに大別できることが 分かった。

(1) 機器の「造り」に関する説明

（2）トラブル発生のメカニズムに関する説明

(3) ショートノートやデータ表など

3 番目の「ショートノート」や「データ表」などは添付ド キュメントとしての性格か溞いものである．また「ショー トノート」にはベテランの「ノウハウ」に相当すると考 えられる記述も目立った 。

以降，この 3 つの知識の表現方法を「機器の造りに関 する知識」，「トラブル発生のメカニズムに関する知識」， 「添付ドキュメント」として検討する .

\section{$2 \cdot 3$ 機器の造りに関する知識}

\section{$\S 12$ つのアプローチ}

保修技術者が機器の造りを考えるとき, 部品の空間的 な配置のみを知っていればよいというものではなく，機 器を構成する部品の機能的な接続あるいは物理的な因果 関係についての理解がなくてはならない．このような「機 器の造りに関する知識」のオントロジーは大きく分けて 「機器の機能と構造の関係を論じる」アプローチと「設 計者の意図と構造の関係を論じる」アプローチの 2 つが ある

「機能と構造の関係を論じる」アプローチには，例え ば，エネルギーなどの保存量が機器の構成要素の間で流 れて機能を実現し，これによって目標が達成される樣子 を表現する MFM (Multilevel Flow Modeling) [Lind 92]や，具体的な「構造」と抽象的な「機能」との間の 抽象度の軸と，部分一全体の包含関係の軸からなる平面上
で機器の動作を説明する Abduction Hierarchy モデル [Bisantz 94] などがある .

「設計者の意図と構造の関係を論じる」アプローチは 知的 CAD の分野で盛んに議論されており，設計意図と 物理的制約から構造が指定される制約伝播のモデル [田 浦 97] などがある.

前者のアプローチは機器動作時の振る舞いの理解に有 効であり，機器の運転員向けのオントロジーであるとい える。一方て保修作業時は一般に機器は停止しており，む しろ保修作業員に必要な知識は, 組み立て時の注意点や 設計上の機器動作の環境的条件など，より設計者の光れ に近いものであるといえる．このような見地から，保修 のために「機器の造りに関する知識」を表現するオント ロジーとして「設計者の意図と構造の関係を論じる」ア プローチを採用するのが妥当であると考える .

\section{$\S 2$ 設計プロセス知識}

古田らは設計に対する要求を満足する設計解を任意に 仮定し,試行錯誤を繰り返すことによって無矛盾な設計解 集合を発見する設計過程の表現モデルを提案した [Furuta 92] . このモデルは外部から与えられる設計要求と, 設計 者が任意に与えたパラメータなどの「仮定」，及び光れ らから物理的な制約により導出される設計仕樣の集合と して表現される .

このモデルを「機器の造りに関する知識」に応用した 場合 , 設計者のセンスに頼るような根拠の記述の困難な 設計内容を仮定されたものとして明示的に扱えるため， 簡明に表現できる。

なお , 古田らのモデルでは設計の試行錯誤の過程で相 互に矛盾する「仮定」を扱う必要があるが，ここでは設 計の完了した対象機器を表現するので他の制約に矛盾し ない「仮定」のみを含む設計解集合を扱う．

本研究では特に「機器の造り」の説明のためにこのモ デルを見直し，次の 4 つの種類の項目が根拠を参照する ためのリンクで接続された「設計プロセスモデル」を提 案する。

の設計要求： 機器の設計意図や環境からの制約など, 設 計解が満足すべき条件.

○設計仕様: 設計作業の結果導出される設計解.

○専門的設計判断：上述の仮定された設計内容であり， 根拠に設計者の判断を暗に含む点を除いて「設計仕 樣」に等しい。

○工学知識: 普遍的な科学知識や技術的知識など.

これらの設計項目はネットワークグラフを構成し，上 位の「設計要求」はより粒度の小さい「設計要求」に分 解され 「工学知識」とともに「設計仕樣」の根拠となる。 「専門的設計判断」は設計仕樣の一種であるにもかかわら ず，根拠が十分である必要がない．

例として原子炉一次系冷却材ポンプ (RCP) の回転数 を決定する設計プロセスを図 1 に示す。 


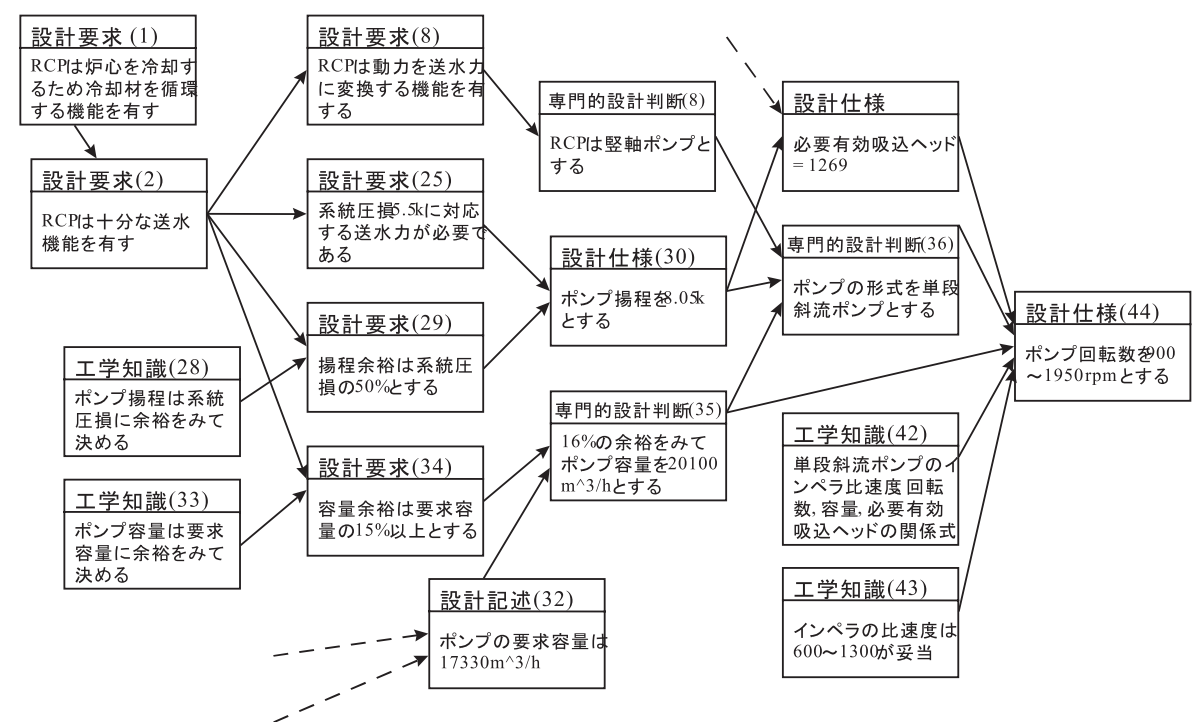

図 1 設計プロセス表現の例

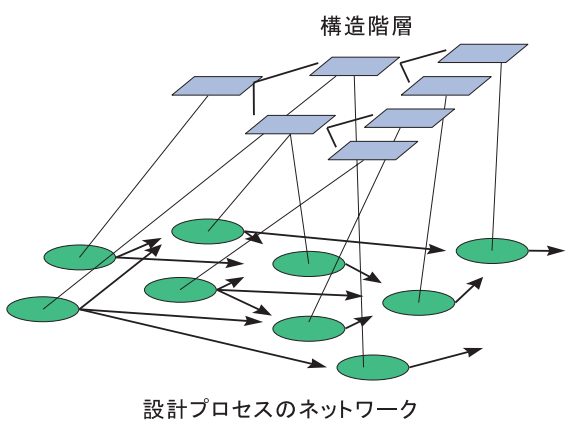

図 2 構造階層によるインデックス

\section{$\S 3$ 構造階層}

田浦らはこのような設計項目を, 設計の結果である「プ ロダクト知識」と呼ばれる構造階層に関連付けて整理す る手法を提案した [田浦 97] .ここで構造階層とは, 対象 機器をトップノードとして，これを構成する内部機器を 全体-部分の関係で階層化していった単純な木構造グラフ である .

設計項目が大量に存在する場合，兰れらは複雑なネッ トワークグラフを構成し, 人間の理解を妨げる可能性が あるが, 構造階層を各設計項目のインデックスとして利 用することにより直感的に全体を把握することができる ようになると考えられる .

また各設計項目を構成機器ごとにまとめることによっ て，時間軸に沿った設計のプロセスという観点ではなく， 特定の機器の設計項目を列挙した機器の解説という観点 で知識を提示することができる．

本研究ではこのように構造階層を利用する手法を導入 し、機器の造りに関する知識」を構造階層のノードにリ ンクさせ，構造階層をインデックスに用いる (図 2).
$2 \cdot 4$ トラブル発生のメカニズムに関する知識

$\S 1$ 故障オントロジー

故障の生起には明示的 , 暗示的に必ず原因と結果の因果 関係が存在しており，これを端的に利用したものがフォー ルトッリーによる故障解析である . しかし來村の故障才 ントロジーの議論 [來村 99] によれば，一口に故障の原 因といっても，機能的な構造から機器の機能喪失の原因 になる要素を推定した「認知的故障原因」と，時間的に 物理現象を遡って原因となる物理現象，あるいは機器の 物理特性を推定した「物理的故障原因」とがある．

ここで保修技術に目を移すと，保修時は運転時ではな いので機能喪失の原因機器を特定することが主眼ではな く，設計を逸脱した機器の状態および環境を回復し，ま たこれを予防することが目的である．つまり保修でいう 故障の原因とは「物理的故障原因」であると考えるのが 適当である。

\section{$\S 2$ 異常事象と外的異常要因}

一般に保修を行うべき事象は，故障のみならず設計を 逸脱した機器の状態や環境を含み，これらを一般的に「異 常事象」と表現することができる.ここで異常が故障とし て顕在化しているかどうかは保修の上では重要ではない．

ところで, トラブルの発生のメカニズムを説明する場 合, 設計時に決まる機器に固有の要素と機器に無関係な 外的な要素との関係を議論する二元論が可能である .

このような二元論の利点は, 機器の異常遷移のシーケ ンスと, 再現性が低い, または原因究明が困難なヒューマ ンエラーや環境的要因などを区別して議論できる点であ る.予想されていなかった原因で発生した異常事象であ るにも関わらず，光れまでに経験されたトラブルと類似 の結果をもたらした場合，違いは外的な要因のみであっ て機器内部では同じ事象が展開している場合が多い．

この二元論に基づくオントロジーを用いて保修技術者 を教育すれば，多樣な外的要因にとらわれず，機器内部 


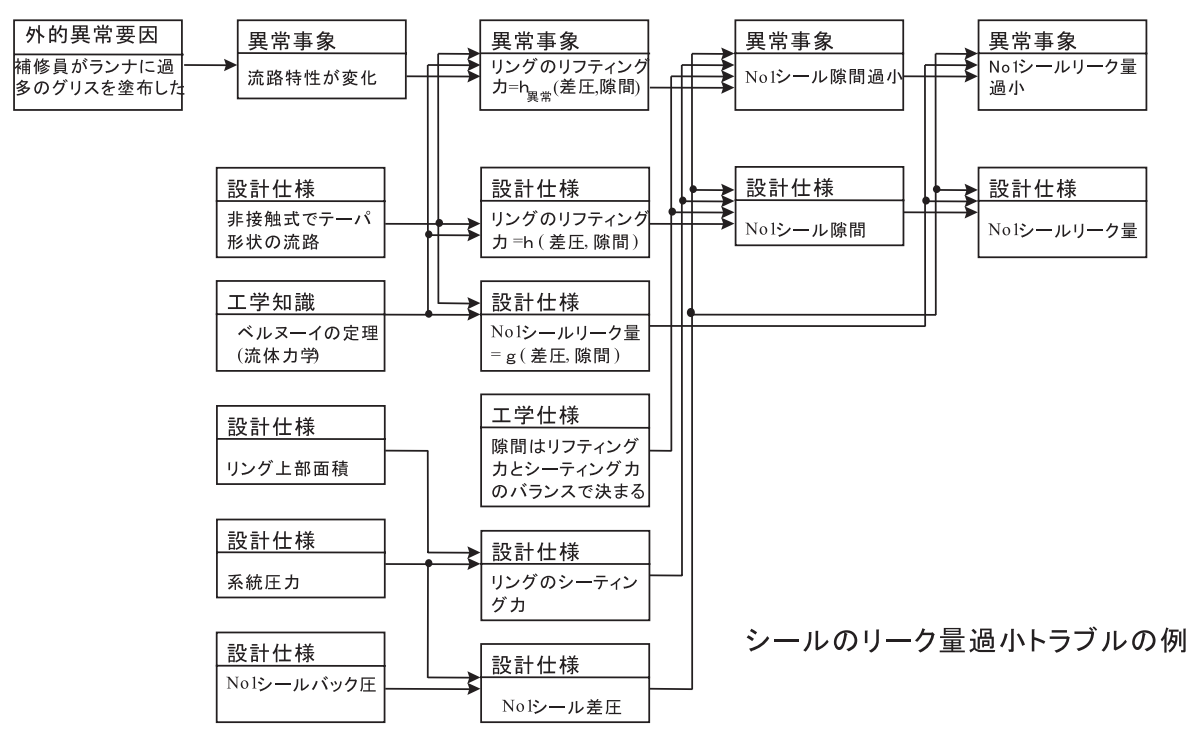

図 3 異常状態遷移の表現の例

の事象に着目してトラブル発生のメカニズムを理解し , 効率的にェラー回避，トラブル予見の能力を身に付けら れる可能性がある .

\section{$\S 3$ 異常状態遷移の知識}

高橋らはプラントの故障診断に用いるエキスパートシ ステムのための知識表現として , 多段階状態遷移過程に よる知識表現モデルを提案した [高橋 92] . 多段階状態 遷移過程とは前異常状態から故障状態が発現し，特定機 能の喪失に至るという形で状態か段階的に遷移する過程 であり，弚の中で光れ光れの段階で重要な役割を果たす 「機器の属性」を議論する．ここで「機器の属性」とは機 器の構造や仕樣などの総称である .

ここで重要なことは，表現の中で設計時に決定される 「属性」が利用されており，また故障を原因から事象発現 に至るプロセスとしてとらえている点で，これは要求か ら仕樣が導かれる設計プロセス知識の表現に類似した表 現方法で表現することが出来ると考えられる．本研究で は , 高橋の故障診断のためのモデルについて , 各状態レ ベルを「保修を行うべき事象」として，先に議論したよ うに「異常事象」にまとめ, 外的な要因の項目を導入し て，設計仕樣とこれらが因果関係で接続された異常状態 遷移メカニズムのモデルを提案する . 具体的な項目は次 の 4 つの種類である .

○異常事象：対象機器内部の設計から逸脱した状態, ま たは光れに類するもの.

○外的異常要因: 異常事象の原因となる対象機器外部 の要因.

設計仕様: 異常事象の原因となる対象機器の仕樣.

○工学的知識: 異常生起のメカニズムを説明する普遍 的な科学・技術知識

「外的異常要因」と「設計仕樣」の組み合わせの結果 $\ulcorner$ 異常事象」が発生し，この「異常事象」がさらに別の 「異常事象」の原因となって，「異常事象」が遷移していく
樣子を表現する．新たな「異常事象」は一般に 1 つ以上 の「異常事象」と「外的異常要因」や関係する「設計仕 樣」によって引き起こされ, 全体として因果ネットワーク を構成する . この表現方法を用いた原子炉一次系冷却材 ポンプのシールリングのトラブルの表現例を図 3 に示す .

これらの要素のうち，「設計仕樣」と「工学的知識」は 「機器の造りに関する知識」の項目である．一般に異常状 態遷移のネットワークは設計プロセスのネットワークの 設計仕樣と有機的に関連しており，2つのネットワーク はいたる所で交差させて表現される（図 4).

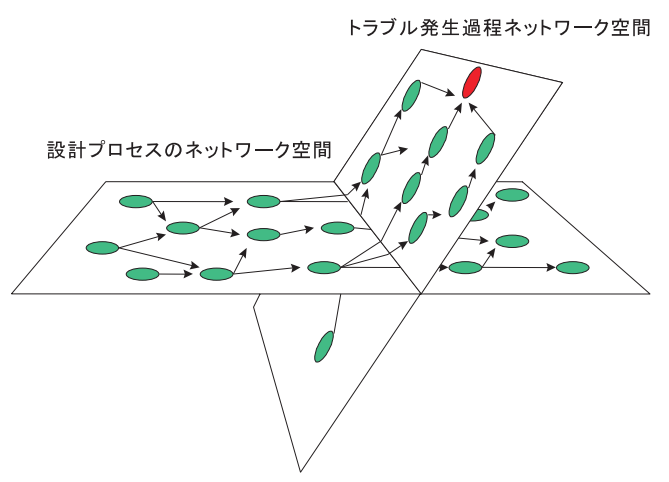

図 42 つのネットワークの交差

また設計プロセス同樣, 異常状態遷移に関する知識も 構造階層に従って整理することで, 時系列の異常状態遷 移のみならず, 構成機器単位で発生する可能性のある「異 常事象」や影響する可能性のある「外的異常要因」を提 示できるようにする .

\section{$2 \cdot 5$ 添付ドキュメント}

一般に講義テキストの中のショートノートやデータ表 などの「添付ドキュメント」は相互の関連が比較的弱く， 主に先の 2 つの知識（「機器の造りに関する知識」と「ト 
ラブル発生のメカニズムに関する知識」) に従属する．

また表現形式は自然言語文章や数值, 図などで構成さ れ，内容も多樣であるため直接高次のオントロジーを議 論することは困難である . 従って以下ではデータの内容 ではなくデータを扱うための知識表現に関する低次の才 ントロジーを検討する .

$\S 1$ 知識表現

相互の関連が比較的弱い「添付ドキュメント」を体系 付けることを考えると，まずタイトルや内容でインデッ クスを作成する方法が考えられるが，元のテキスト上の コンテキストに関する情報が失われてしまい, 利点が少 ない。

「機器の造りに関する知識」と「トラブル発生のメカ ニズムに関する知識」への従属性を反映するためには， これらの知識項目からリンクを張って参照することが妥 当であるように見える．またテキストの趣旨から「添付 ファイル」は対象機器についての情報であることが前提 であるので, 少なくとも構造階層上のいずれかの構成機 器へのリンクは一意に存在するはずである .

従って「添付ドキュメント」はすべて構造階層上のい ずれかの構成機器に関連付け, また必要に応じて「機器 の造りに関する知識」と「トラブル発生のメカニズムに 関する知識」の知識項目へ関連付け，これらのネットワー クグラフにぶらら下げるべきである .

$\S 2$ データ形式

オントロジーの議論から外れるが , 教育支援システム 実装に向けて「添付ドキュメント」のデータ形式について も検討しておく . マルチモーダルなドキュメントをワー プロソフトや表計算ソフトなど適切なファイル形式で格 納するのも一つの方法であるが, この場合, 汎用性が著し く損なわれることになる. 本研究では沉用的にマルチメ ディア情報を扱うために HTML (Hyper Text Markup Language) を利用して「添付ドキュメント」を用意し， 知識項目とする .

\section{$2 \cdot 6$ 保修オントロジーのまとめ}

保修の教科知識をたたき台に保修オントロジーを議論 した．また具体的な成果として「機器の造りに関する知 識」と「トラブル発生のメカニズムに関する知識」及び 「添付ドキュメント」をネットワークグラフとし, 各要素 のインデックスとして構造階層を利用した知識表現を導 出した . 提案した保修オントロジーは以下の内容を表現 する能力を持つ .

(1) 具体的な機器の仕樣 .

(2) 仕樣が定められた設計上の根拠 .

(3) 具体的な機器の異常状態 .

(4) 機器の異常状態の原因となる外部の要因 .

(5) これらの因果関係 .

(6) 構成機器の全体-部分の関係.

（7） (1)〜(4) と各構成機器との対応関係 .
提案したオントロジーは対象に具体的な機器構造を想 定しており，簡明さを優先して構成機器の抽象的なカテ ゴリ分類などは許していない．また「保修タスク実施知 識」の背景知識である「教科知識」を表現することを主 眼としており,「保修タスク実施知識」の表現は考慮して いない .これらの制限から，以下のような内容はこの才 ントロジーで扱うには不便であるか，あるいは直接的に 扱うことはできない .

（1）部品に使われる金属の一般的性質など, 複数の構 成機器に共通する内容 .

(2) 作業手順などのタスク知識に関する内容.

(3) 弚の他，作業員の健康管理や組織のマネージメン 卜など，この枠組みで考慮されていないもの.

ただし複数の構成機器に共通する内容は, 構造階層にお ける弚れらの上界的な構成機器にリンクすることで便宜 的に扱うことができる場合がある．また直接扱えない内 容のためには，例外的な情報を「添付ドキュメント」と してカプセル化して利用できる低次のオントロジーが組 み込まれており，応用に備えている。

\section{3. 経験的知識の共有}

\section{$3 \cdot 1$ ベテランの知識}

熟練した保修技術者は, 弚の経験から, 保修要領書な どに明記されていない樣々な知識 (ノウハウ) を培って いる. 熟練した保修技術者と乥うでない人との差はこの 「ノウハウ」の有無にかかっているといえる .

これらの「ノウハウ」は一般に膨大で, 一つ一つは些 細で, 体系だっておらず，根拠の説明も困難である .こ のような情報は単一の文章としては記述しづらく，また 検索のための画一的な手段もないことから再利用がされ にくい．ここで保修技術者の世代交代に伴う技術の伝承 のために「ノウハウ」を記述，参照する手法を提案する ことは意義のあることと考える.

\section{$3 \cdot 2$ 知 識 表 現}

これまでべテラン保修員の持つノウハウの背景知識を 明示化するために保修オントロジーを定式化したが，具 体的に構筑されるドメインオントロジーは保修について の「基本概念の体系」として機能するので, ノウハウの 記述及び検索に効果的に利用できると考えられる．

すなわち，ノウハウを記述する際に関連する保修オン トロジー項目を明示しておくことで，ノウハウをゼロか ら記述するよりも説明を大幅に省略でき，またこの「基 本概念の体系」から関連するノウハウ記述の検索が可能 になることが期待できる . 教育支援システムでの応用例 としては，これまでテキスト資料の余白にノウハウのメ モを書き込んでいた作業を，計算機上で害施することが できる .

具体的な知識表現としては, 自然言語による記述を保 
修オントロジーと関連付けることが自然であると考えら れる.これは既に「添付ドキュメント」として定式化し た表現方法を谷のまま利用できるので，先に提案した知 識表現に特別な拡張は必要ない.

乥こで教育支援システムにドキュメント入力機能を装 備し，これまで述べたような知識表現を利用するという 方法で，ここに経験的知識を共有する方法論を提案する． なおこの教育支援システムを知識共有システムとして見 た場合，教科知識は「ノウハウ」を参照するためのイン デックスの役割を果たす .

\section{4. 試作システム}

これまで検討した知識表現を用いてデータベースとイ ンタフェースプログラムを作成した .

\section{$4 \cdot 1$ データベース}

リレーショナルデータベース上に「構造階層」と「教 科知識」を構築した .ここで「構造階層」のレコードは 各構成機器の名称や外観図などを保持する「教科知識」 の「型」はここまでの保修オントロジーの議論を反映し て設定した (表 1$)$.

表 1 教科知識データの「型」がとる值

\begin{tabular}{|l|l|}
\hline \multicolumn{1}{|c|}{ 型の値 } & \multicolumn{1}{c|}{ 定義 } \\
\hline \hline 設計要求 & 対象機器の仕樣が満たすべき条件. \\
\hline 設計仕樣 & 対象機器の仕樣を記述したもの. \\
\hline 専門的設計判断 & 設計者の判断が含まれる設計仕樣. \\
\hline 工学知識 & 普遍的な科学・技術知識. \\
\hline 外的異常要因 & 対象機器外部の異常要因. \\
\hline 異常事象 & 対象機器の内部状態の異常. \\
\hline トラブルモード & 異常遷移の OR 接続を表す項目. \\
\hline 添付ドキュメント & 関連情報の所在を URL で示す. \\
\hline
\end{tabular}

\section{$4 \cdot 2$ インタフェース}

プロトタイプソフトウェアは Microsoft Windows 上で実装した。

ここでプログラムのインタフェースには学習者への樣々 な配慮が必要である . 例えばプログラムは特別な訓練を 行わずに利用できるような操作体系が実装されているこ とか望ましい．また知識の提示の仕方についてもより直 感的で分かりやすい方法を検討するべきである．

操作体系については実装 OS の標準シェルでありWeb ブラウザとしても有名な「Internet Explorer」のメタフ アーを踏襲し，直感的なアイコン表示・マウス操作を基 本として操作法を類推しやすいように配慮した .

この操作画面を図 5 に示す . 左上部のパネルは構造階 層をクリッカブルマップで提示する . 具体的には対象と

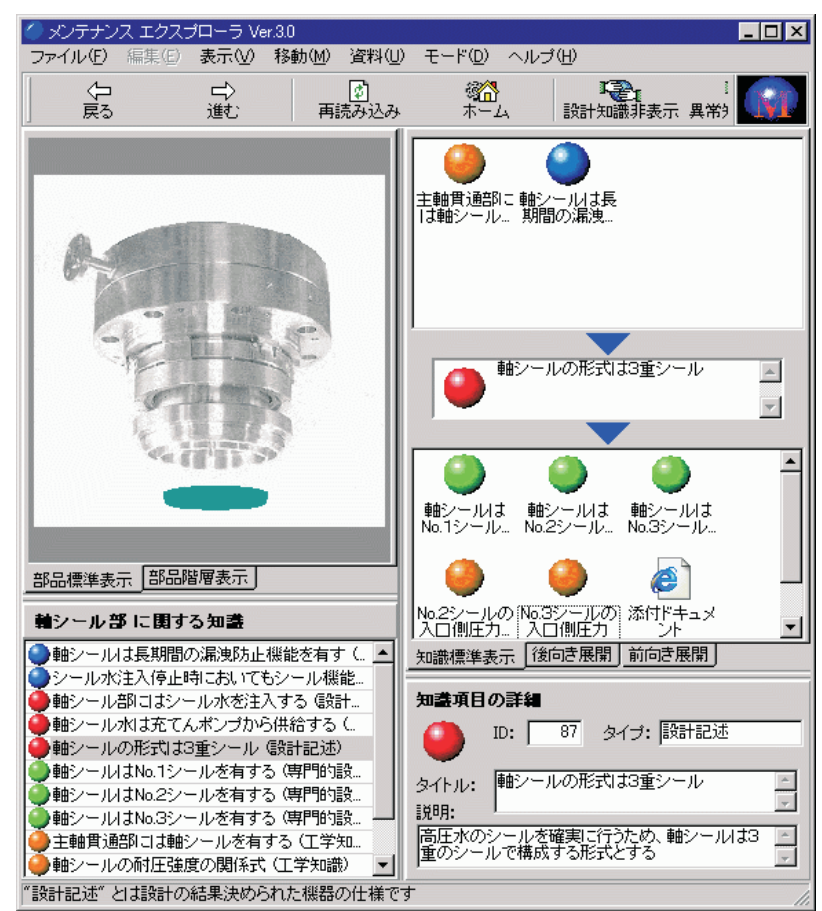

図 5 Maintenance Explorer ver.3.0

する構成機器の外観図を表示し，機器の構造に対する直 感的理解を助けるとともに,クリック操作による構成機 器の選択が可能になっている . 左下部のパネルには選択 された構成機器に関する「機器の造りに関する知識」「ト ラブル発生のメカニズムに関する知識」及び「添付ドキュ メント」が一覧表示され，ここで選択された知識につい て , 右パネルにネットワークグラフのリンク関係と詳細 が表示される .

「添付ドキュメント」は Web ブラウザを利用して内容 を表示する．また任意の知識項目に関連付けて「添付ド キュメント」を新規作成することができ，あらかじめ指 定された HTML エディタを自動起動して編集すること ができる

\section{5. 評 価}

\section{$5 \cdot 1$ 評 価 方 法}

学習支援の内容が，保修タスク产のものではなく保修 に関する背景知識であることから，効果を客観的に観察 することは現実的には困難であると考えられる．乥こで 評価は対象機器の保修業務に関する十分な知識を持った エキスパートによる学習支援システムの主観評価を主体 とする . 具体的には以下の手順で行う

(1) 用意した標準問題を開発した学習支援システムを 用いて被験者に解いてもらう.

(2) 学習支援システムに関するアンケートを実施する . ここで標準問題は

・指定された設計仕樣について，学習支援システムを 参照して得られる知識で説明する . 
・指定されたトラブル事例について，学習支援システ ムを参照して得られる知識て説明する。

・指定された文献を「添付ドキュメント」として入力 する .

の 3 つである . アンケートは以下の項目についての 5 段階 評価の設問と, 光れら評価の理由など自由記述の設問か らなる. 5 段階評価については, システムのインタフェー スなど実装の仕方で左右される評価と知識表現に関する 評価を分離するように設問の章立てを配慮した。

・システムのインタフェースに関する設問

○操作の方法は直感的に分かりやすいか.

○操作の実施は容易か.

○ウインドウの構成は見やすいか.

○アイコン表示は分かりやすいか.

・システムの機能・性能に関する設問

○動作にストレスはないか.

。「添付ドキュメント」の閲覧は容易か.

。「添付ドキュメント」の作成は容易か.

○テキストと比べて知識の探索は容易か.

・データ構成・表現方法に関する設問

○データ数は十分か.

○知識の説明は分かりやすいか.

$\circ$ 知識型の分類は適当か.

○テキストと比べて機器の構造は分かりやすいか.

○テキストと比べて設計仕樣は分かりやすいか.

○テキストと比べてトラブル発生のメカニズムは分 かりやすいか.

・総合的な設問

○テキストと比べて教示内容は理解し，覚えやすいか. 「添付ドキュメント」の閲覧に用いる Web ブラウザには Microsoft Internet Explorer ver. 5.0 を用い, HTML エディタとしてはこれに同梱されている FrontPage Express ver. 2.0 を用いた .

評価に協力した被験者は原子力発電所の保修業務経験 者 10 名であり，保修業務の経験年数は 2 年から 19 年で ある

\section{$5 \cdot 2$ 例題として用意した知識}

保修対象機器には原子炉一次系冷却材ポンプを選び， 「ポンプ主軸シール部」の典型的なトラブル 2 例と , ポン プ全体の設計情報（特に「ポンプ主軸シール部」付近に ついて充実させたもの) とを「教科知識」として 139 項 目，構造階層 17 項目を専門家の協力で用意した . 内訳を 表 2 に示す.

\section{$5 \cdot 3$ 評 価 結 果}

5 段階評価による 10 人の評価結果の平均値を図 6 , 図 7 に示す。

与えた標準例題の「トラブル事例の説明」では, 全般 に「ポンプ主軸シール部」のパラメータである「テーパ

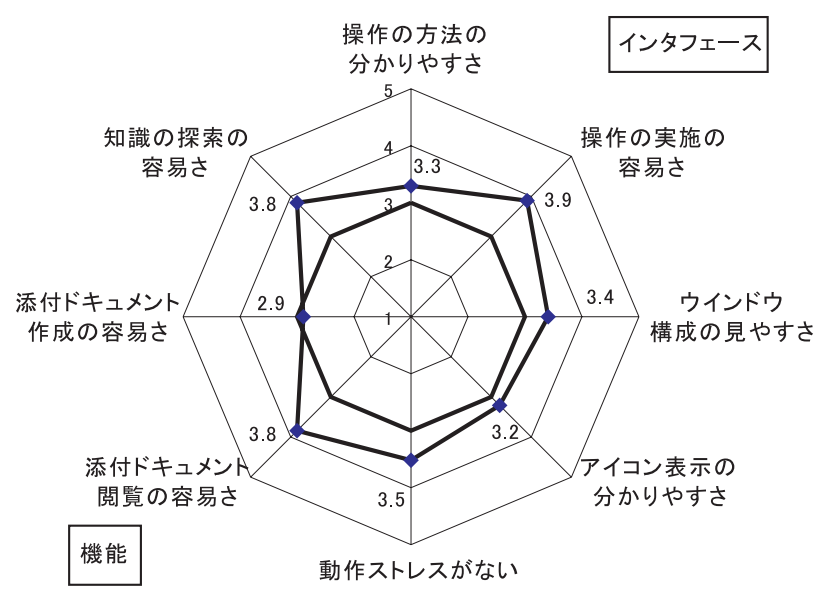

図 6 開発したプログラムに関する評価

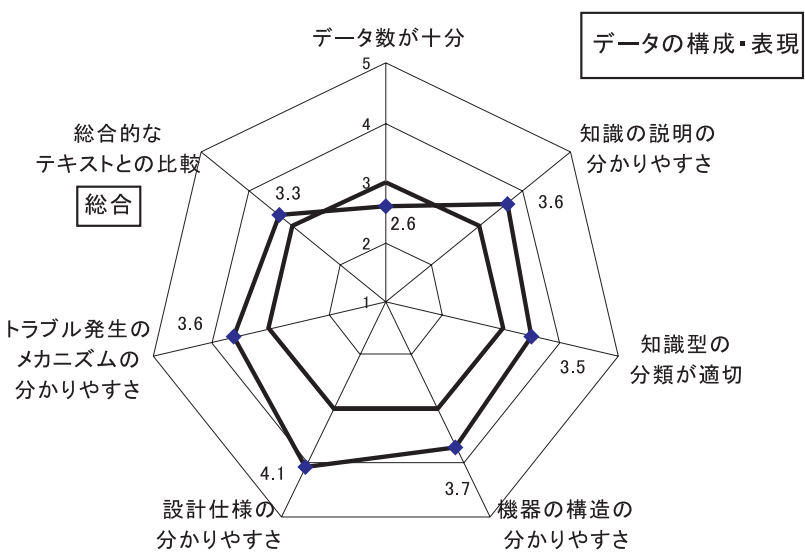

図 7 教科知識に関する評価および総合評価

量」を用いた説明がなされた 。

また，「データ構成・表現方法に関する設問」の記述式 の回答には、図が足りない」「詳細説明が不足である」， 「寸法などが分からない」といったデータ不備の指摘のほ か，「表現がくどい」,「表現方法になじみがない」といっ た意見が寄せられた . 兴のほか，「資料作成の容易さ」で 作成しにくいと回答した被験者の理由記述には「評価に 用いた HTML エディタの使い方が分かりづらい」と述 ベられていた .

\section{6. 考察と今後の課題}

5 段階評価の平均はおおむね 3 以上の肯定的な評価で あり，特に「操作の実施の容易さ」および「設計仕樣の

表 2 例題の項目数

\begin{tabular}{|l|r||l|r|}
\hline 項目 & 項数 & 項目 & 項数 \\
\hline 設計要求 & 36 & 添付ドキュメント & 5 \\
設計仕樣 & 35 & 外的異常要因 & 1 \\
専門的設計判断 & 15 & 異常事象 & 9 \\
工学知識 & 36 & トラブルモード & 2 \\
\hline
\end{tabular}


分かり易さ」で評価が高かった，一方で「資料作成の容 易さ」および「データ数が十分」で評価が低かった .

「資料作成の容易さ」で評価が低いことに関しては, 評 価に用いた HTML エディタの問題であり，本研究で作 成した教育支援システムの本質的な問題ではないと考え られる.また「デー夕数が十分」でないとされる点に関 しては, 研究のために入手できる機器開発に関する資料 の量的な制限によるものである .

知識表現について:

標準例題の「トラブル事例の説明」では設計仕樣であ るパラメータが参照されており, トラブル事例の理解に 設計情報が寄与することが示された .

「インタフェース」及び「機能」に関する設問は, 試 作システムの実装に依存する評価である．また「データ 構成」に関する「デー久数が十分か」及び「知識の説明 が分かりやすいか」の設問は用意した例題データに依存 する評価であり，共に知識表現の評価のための条件の良 さ，または悪さの指標であると考えることができる．図 7 で「データ数が十分」でないとされている点で, 知識 表現の評価のための条件がやや悪い，一方，知識表現に 関してテキストと比較した 4 つの設問を含む「データ構 成・表現方法に関する設問」及び「総合的な設問」で評 価が高いことは，知識表現の有効性すなわち提案した保 修オントロジーの有効性を示しているといえる。

試作システムについて:

「インタフェース」に関する評価か高いのは「Internet Explorer」の周知の操作性を真似たことが原因である可 能性が高く，教育支援システムのインタフェース設計の アイデアとして興味深い .

自由記述に関しては知識のグラフ表現に対する被験者 の戶惑いを見て取ることができるが，残念ながらデータ の拡充以外に知識表現に関しての具体的な改善の提案は 得られなかった .

今後の課題として, 本研究では背景知識ではないとし て無視した「保修タスク実施に関する知識」を含むよう な一般的保修オントロジーへの拡張も重要であると思わ れる。

\section{7. ま と め}

保修に関する背景知識のオントロジーを，原子力分野 で教育に利用される印刷物を参考にして議論した .また 保修に関する教育支援システムにベテランのノウハウを 動的に取り込んで共有する方法についても提案した .こ れらの成果として教育支援システムのための知識表現を 提案した。

この知識表現を利用した教育支援システムを開発し， 提案した知識表現の有効性を評価した .

\section{$\diamond$ 参 考 文 献 $\diamond$}

[Bisantz 94] Bisantz, A. M. and Vicente, K. J.: Making the abstraction hierarchy concreate, Int. J. Human - Computer Studies, Vol. 40, pp. 83-117 (1994).

[Furuta 92] Furuta, K. and Kondo, S.: Framework for AIBased Nuclear Reactor Design Support System, Journal of Nuclear Science and Technology, Vol. 29, No. 5, pp. 415-421 (1992).

[Ishii 96] Ishii, H., Kashiwa, K., Tezuka, T., and Yoshikawa, H.: Development of Machine-Maintenance Training System using Petri Net and Virtual Environment, CSPEC 96, pp. 138-143 (1996).

[來村 99] 來村, 溝口: 故障オントロジー, 人工知能学会誌, Vol. 14, No. 5, pp. 828-837 (1999).

[久保田 93] 久保田, 佐藤, 氏田, 横田 : 魅力ある CAI システム の開発, 人工知能学会研究会資料, SIG-IES-9303-13, pp. 73-78 (1993).

[久保田 96] 久保田, 佐藤, 横田, 川上: 原子力発電所の教育・訓 練システム, 人工知能学会研究会資料, SIG-IES-9602-02, pp. 7-12 (1996).

[Lind 92] Lind, M., Larsen, M. N., and Osman, A.: Applications of Multilevel flow Modeling, in Proc. of AMP '92 Vol. IVAtomic Energy Society of Japan (1992), Session 42.

[溝口 95] 溝口理一郎: 知的教育システム, 情報処理, Vol. 36, No. 2, pp. 177-186 (1995).

[溝口 97] 溝口, 池田 : オントロジー工学序説, 人工知能学会誌, Vol. 12, No. 4, pp. 559-569 (1997).

[高橋 92] 高橋, 北村, 椙山 : 原子炉診断への応用を目的とした故 障生起汎化知識の表現, 日本原子力学会, Vol. 34, No. 7, pp. 678-692 (1992).

[田浦 97] 田浦俊春 : 設計の説明と理解のためのヒストリーベー ス, 新工学知 1 - 技術知の位相, 東京大学出版会 (1997).

[横山 93] 横山, 氏田, 加藤, 谷川 : 緊急時運転手順の知的 CAI シ ステム, 人工知能学会研究会資料, SIG-IES-9302-13, pp. 32-36 (1993).

〔担当委員 : 新田克己〕

2000 年 5 月 15 日 受理

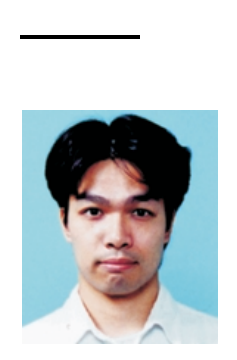

者 紹 介

\section{尾暮 拓也(学生会員)}

1997 年東北大学工学部原子核工学科卒業, 1999 年東京 大学大学院工学系研究科システム量子工学専攻修士課程修 了. 現在同博士課程. 日本原子力学会会員.

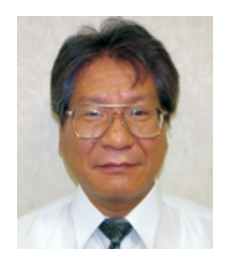

花房 英光

1981 年慶應義塾大学工学部機械工学科卒業. 1983 年同 大学院工学研究科修了. 同年関西電力 (株) 入社, 保修業 務に従事. 1997 年 (株) 原子力安全システム研究所技術 システム研究所出向 . 現在原子力発電所の保守支援に関す る研究に従事。

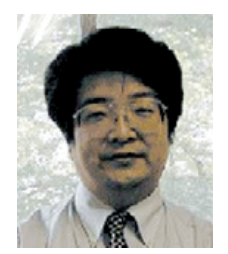

古田 一雄(正会員)

1981 年東京大学工学部原子力工学科卒業, 1986 年東京 大学大学院工学系研究科博士課程終了 (工学博士), 同年 電力中央研究所, 1987 年東京大学工学部講師, 1989 年同 助教授, 1999 年東京大学新領域創成科学研究科教授. 専 門は認知システム工学. 日本原子力学会, ヒューマンイン タフェース学会, ANS などの会員. 